\title{
Gender, work and migration: Reflections on feminist geography contributions and challenges
}

\section{Patricia Yocie Hierofani}

Uppsala University, Sweden

In 1991, Linda McDowell's article 'Life without Father and Ford: The New Gender Order of Post-Fordism' (McDowell, 1991) was published. The article is a classic example of feminist geography critiques of human geography - or, in this context, economic geography - for excluding women as subjects and gender as an analytical category. Yet almost a quarter of a century later, feminist geographers still struggle for our place in the discipline.

This commentary aims to provide some reflections on the contributions of feminist geography in economic geography from gender, work and migration perspectives. Linda McDowell's article 'Life without Father and Ford' is used as a starting point of the discussion, which will be followed by a brief overview of the contributions of feminist geography in gender, work and migration literature and a reflection on the constant challenges. This commentary originated from the discussion at the 'Feminist Economic Geography: What Difference does Difference Make?' Panel at the Fourth Global Conference on Economic Geography, Oxford, 2015, which was organized as a tribute to McDowell's works. This commentary is therefore not intended to provide a comprehensive review of feminist geography works.

To give a little background about myself, I am originally from Indonesia but I have been living in Sweden for more than six years. Previously, I worked as a staff at the National Commission on Violence against Women in Indonesia. The experience gave me initial empirical knowledge on the exploitation of Indonesian women domestic workers abroad. I have since gained academic knowledge in gender studies and human geography as part of my graduate education. Most literature I read is in English, although I also follow works of scholars from Southeast Asia. This mixed background shapes the kind of knowledge I gain and pursue throughout my life. At the same time, it makes me sensitive to gender, class, race questions and other categories of 'difference' which are often taken for granted.

\section{'Life without Father and Ford'}

In 'Life without Father and Ford' (McDowell, 1991), McDowell criticizes two influential post-Fordist theories, i.e. the regulation school and the flexible specialization approach, for

\footnotetext{
Corresponding author:

Patricia Yocie Hierofani, Uppsala University, Uppsala, Sweden.

Email: Patricia-Yocie.Hierofani@kultgeog.uu.se
} 
making assumptions about gender relations and for neglecting gendering processes in their analyses. Although the regulation school connects the changes in production with reproduction and labour market with household and family, McDowell argues they are ignorant to gender relations in post-Fordist restructuring. As a result, while they note the increasing participation of women in the labour market, they fail to see the sharpening gender segregation in labour market where women are positioned at the bottom of the labour hierarchy. McDowell shows that in reality in Britain the post-Fordist restructuring causes impacts on gender divisions, from changes in the labour market, in social relations ('domestic' life), to increasing inequalities between households.

\section{5 years 'without Father and Ford'}

After almost 25 years since the article was published, feminist geography has enriched the discourses in economic geography in a unique way. Regional development may still be a central concern for economic geographers, but economic geography as a field itself is growing. In the introduction to the 10 years edition of The End of Capitalism (As We Knew It), for example, J. K. Gibson-Graham writes about how the academic world has changed with the flourishing discussions on economic alternatives, in comparison to the time when they wrote the book (2006). By putting the narratives of women in the cartographies of the 'economic', feminist geography challenges the 'neutral' economic indicators as gendered and offers alternative understandings.

Joining wider feminist discourse on reproduction, feminist geographers argue that reproductive work is an integral part in capitalist production. The household inevitably becomes an important economic unit because it is where women's practices of reproduction, consumption and production take place (e.g. home-based production). In doing so, feminist geography broadens the notion of 'workplace' to include those outside the formal workplaces and criticizes the production/reproduction, public/private divisions. With this, feminist geography sheds light on the (de)valuation processes of skills and labour in the gendered divisions of labour. Through the works on embodiment, which have flourished since the 1990s, feminist geography articulates the lived experiences of women and other marginalized groups.

Feminist migration literature in geography contributes in shifting the conception of migration spaces from merely economic to cultural by bringing migrants' experiences into the picture (for more comprehensive reviews on the contributions of feminist geography on economic geography from the transnational migration perspectives, see Silvey, 2012 and on wider migration studies, Silvey, 2004). Narratives of migrants' identities, embodiment and socio-cultural ties across transnational migration spaces as shown in feminist geography analyses deconstruct the simplistic economic calculation of push and pull factors of migration. These alternative narratives at the same time show the interlinkages between economic globalization processes at the macro level and lived experiences of individual migrant workers at the micro level.

\section{Remaining challenges}

Despite these wonderful achievements, I think feminist geography still faces two major challenges in the discipline. First, there is need to deconstruct the masculine, middle-class, white, heteronormative, able-bodied and other biases in the discipline. As an Indonesian woman in the Swedish academic world, working on relatively marginalized issues, I often got a question: why would Sweden invest in hiring you, an Indonesian researching on 
Indonesian migrant domestic workers in Malaysia, as a $\mathrm{PhD} ?^{1}$ As I enter the fourth year of my $\mathrm{PhD}$ position, I am honestly out of energy to respond to this question. Audrey Kobayashi (2006) points out the irony of the low and stagnant number of women of colour in the geography discipline in English-speaking countries, although the studies of racism and other forms of discrimination are increasing. A quota system for women of colour, or other marginalized groups, is not a solution to deconstruct this long list of biases, but it is an important step to recognize the marginalization in the first place. It should be followed by providing proper space for members of marginalized groups to contribute in the disciplinary discourses. At the same time, there is also a danger in justifying the critical and openness characteristics of our discipline by merely showing the increasing, if any, number of marginalized group members in the discipline.

One way to avoid the 'add and stir' approach is to apply intersectionality. It is a term coined by Kimberle Crenshaw $(1989,1991)$ to show the marginalization of domestic violence against women of colour in the US in feminist discourses and anti-racist discourses. Crenshaw (1991) argues that the two strands of discourses ignore the intersection of identities of women of colour, i.e. women and coloured. It is not until recently that feminist geography starts to engage with the feminist discussions on intersectionality. I am grateful to be mentored by Irene Molina, who is among those introducing intersectionality in Sweden (see e.g. de los Reyes et al., 2002; Molina, 2007). Among recent works in the Englishspeaking literature are articles by Gill Valentine (2007) and Linda McDowell (2008). While the latter two are rather caught up in the methodological aspect of intersectionality, one of the important critiques by Crenshaw (1991) is that feminist discourses and anti-racist discourses politicize the intragroup differences and therefore reinforce the marginalization of the women of colour. It is thus important to recognize the hidden biases in our disciplinary discourses and the intersection of these categories of 'difference' in reinforcing marginalization.

Second, there is an urgent need to incorporate feminist discourses in the wider discourses of the discipline as the impact of feminist geography remains to be seen. As I argued previously, feminist geography has enriched the economic discourses on gender, work and migration, but these works are done almost solely by woman geographers and have limited impact on wider disciplinary discourses. McDowell (1993) in a review on the contributions of feminist geography in the 1980s-early 1990s raises a critical point: 'The problem of sexism in geography lay neither (or rather not solely) in the gender composition of its practitioners nor in the gender blindness of its subject matter but at the theoretical and analytical level' ( $p$. 161). There is a need for feminist geography to continuously rework our analyses and theories and to engage our (men) colleagues in our academic excellence. The article 'Locating Globalization: Feminist (Re)readings of the Subjects and Spaces of Globalization' by Richa Nagar et al. (2002) is an excellent example of feminist initiative to engage economic globalization scholars in feminist analyses and to show how economic globalization researchers could benefit from feminist epistemologies and methodologies.

\section{Hope for future works}

When McDowell assesses the intellectual contributions of feminist geography to the construction of knowledge in the discipline, she argues, 'The structures of power that affect the disciplinary discourse remain relatively immune to feminist critiques. And yet there has been progress' (McDowell, 1993: 157). I find the statement to be both depressing and hopeful. It is true that feminist geography has enriched the landscape of economic geography. Nevertheless, there is still a grave need for constructive dialogues to 
deconstruct the masculine, middle-class, white, heteronormative, able-bodied and other biases in human geography as in the discipline and to incorporate feminist geography analyses into the wider disciplinary theoretical, methodological and analytical discourses. Without a genuine dialogue, what happens is precisely what the panel organizers question here, 'What difference does difference make?'

\section{Acknowledgements}

I would like to thank the organizers of the 'Feminist Economic Geography' Panel at the Fourth Global Conference on Economic Geography, 2015, Julie MacLeavy, Sue Roberts and Kendra Strauss for organizing a very important panel, and other panellists, Wendy Larner, Jane Pollard, Mary Ann Feldman, Jamie Winders and Barbara Ellen Smith for an intellectually stimulating panel. This text also benefitted from thoughtful comments from Carol Ekinsmyth, and Björn Jacobsen. I would like to give my appreciation to Linda McDowell for such inspiring works.

\section{Declaration of conflicting interests}

The author(s) declared no potential conflicts of interest with respect to the research, authorship and/or publication of this article.

\section{Funding}

The author(s) received no financial support for the research, authorship and/or publication of this article.

\section{Note}

1. In the Swedish education system, PhD students are employed as researchers in universities, and almost all universities are publicly funded.

\section{References}

Crenshaw K (1989) Demarginalizing the intersection of race and sex: A black feminist critique of antidiscrimination doctrine, feminist theory, and antiracist politics. University of Chicago Legal Forum 1989: 139-167.

Crenshaw K (1991) Mapping the margins: Intersectionality, identity politics, and violence against women of color. Standford Law Review 43(6): 1241-1299.

De los Reyes P, Molina I and Mulinari D (eds) (2002) Maktens olika förklädnader. Kön, klass \& etnicitet $i$ det postkoloniala Sverige (The Changing Faces of Power: Sex, Class \& Ethnicity in Post-colonial Sweden). Stockholm: ATLAS.

Gibson-Graham JK (2006) The End of Capitalism (As We Knew It). Minneapolis, MN: University of Minnesota Press.

Kobayashi A (2006) Why women of colour in geography? Gender, Place and Culture 13(1): 33-38.

McDowell L (1991) Life without father and ford: The new gender order of post-fordism. Transactions of the Institute of British Geographers 16(4): 400-419.

McDowell L (1993) Space, place and gender relations: Part I. Feminist empiricism and the geography of social relations. Progress in Human Geography 17(2): 157-179.

McDowell L (2008) Thinking through work: Complex inequalities, constructions of difference and trans-national migrants. Progress in Human Geography 32(2): 491-507.

Molina I (2007) Intersektionella rumsligheter (Intersectional spatialities). Tidskrift för genusvetenskap, tgv, Tema Arkitektur och boende 3: 7-21. 
Nagar R, Lawson V, McDowell L, et al. (2002) Locating globalization: Feminist (Re)readings of the subjects and spaces of globalization. Economic Geography 78(3): 257-284.

Silvey R (2004) Power, difference and mobility: Feminist advances in migration studies. Progress in Human Geography 28(4): 490-506.

Silvey R (2012) Gender, difference, and contestation: Economic geography through the lens of transnational migration. In: Barnes TJ, Peck J and Sheppard E (eds) The Wiley-Blackwell Companion to Economic Geography. West Sussex: Blackwell Publishing.

Valentine G (2007) Theorizing and researching intersectionality: A challenge for feminist geography. The Professional Geographer 59(1): 10-21. 